\title{
The depiction of Mkabayi: A review of her praise poem
}

\author{
Norma Masuku \\ Department of African Languages, University of South Africa \\ P.O. Box 392, UNISA 0003, Pretoria, Republic of South Africa \\ masukn@unisa.ac.za
}

\begin{abstract}
Various research projects have been conducted on the portrayal of women in the different genres of literature. Most scholars who focus on the depiction of women in literature agree that women are sometimes depicted unfairly in literature. Women are often stereotyped as the whore, the ingénue, the docile person, the femme fatale or the witch. The aim of this article is to depict Mkabayi's character by analysing her praises. This type of research was also undertaken by Turner in 1988. Her published article entitled 'Comparison of the izibongo of the Zulu royal women, Mkabayi and Nandi' provides an in-depth analysis of the praises of these women. In her analysis, Turner focuses on the aspects of theme, poetic technique and historical allusions. The aim of this article is also to focus on the theme of Mkabayi's praises, by accentuating her character. However, a different perspective will be adopted since this analysis intends to depict Mkabayi from a feminist perspective. The question this article intends to answer is whether Mkabayi's praises reflect that she was accorded the respect and the honour she deserved as a female leader.
\end{abstract}

\section{Introduction}

Praising is one of the ways of life of African people. Praise poems for kings and queens were composed by a bard. Traditionally, bards were males who had to stay with and live near to the king. Praises are not only composed about important personages such as kings, princes, headmen and national heroes, they are also composed for women, young boys, children, dancers and even animals. The subject of the praise poem may include anything from people to inanimate objects. We can therefore speak of poems composed in praise of practically anything. Praises may be composed by a person about an object dear to him. In this case, as would be expected, the person usually showers himself or the object with praise. Unfortunately, ordinary people did not enjoy the luxury of owning a bard to sing their praises. This was a privilege enjoyed only by kings and the elite.

The praises of royal women were mostly concerned with their appearance, their lineage and their behavioural patterns. Little was recited about them because they played no part in making decisions on how the country was ruled. The ruling of a country was normally the prerogative of men. Hence, the praises of kings are normally associated with feats of bravery and victories in battle.

In most cases, the praises of royal women were used as salutations or greetings by both men and women upon their arrival at the royal home, by the women attending the queen, and as thanks by the men after they had eaten food that was prepared by the royal lady. In the latter case, it would not be necessary to repeat the whole praise poem; it would be considered sufficient to call out a single praise name, such as Msizi! (Gunner, 1991:253).

Various research projects have been conducted on the portrayal of women in the different genres of literature. Most scholars who focus on the depiction of women in literature agree that in most cases women are depicted unfairly through the stereotypes that are often attached to them: the whore, the ingénue and the docile person.

These stereotypes were inspired by the fact that most societies are patriarchal and the writer's view was influenced by his/her socialization. As far as Zulu culture is concerned, a woman was accorded a higher status than her children, although a male child's status was slightly higher than that of his mother. All decisions pertaining to the ruling of the country were a male prerogative. Power was vested in the hands of males. The destiny of the girl was marriage and childbearing. 
Mkabayi ascended the throne when it was uncommon for a woman to do so. The question to think about is: do Mkabayi's praises, being a woman, accord her the respect and the honour she deserved? Do they reflect that she was regarded as a leader who would promote the interests of the country and raise the country's standing? Was it worth her while to put the interests of her country first at the expense of marriage and childbearing?

The aim of this article is to answer the above questions by revisiting the praises of Mkabayi. A similar piece of research was undertaken by Turner in 1988. In her article entitled 'Comparison of the izibongo of the Zulu royal women, Mkabayi and Nandi', Turner gives an in-depth analysis of the praises of these women. In her analysis, Turner focuses on theme, poetic technique and historical allusions.

This article will also focus on the theme of Mkabayi's praises; however a different perspective will be adopted, since this analysis intends to depict Mkabayi from a feminist angle. An attempt will be made to reaffirm that even historically speaking, Zulu women, given the same opportunities and privileges as men, can perform at a comparable level.

\section{Views on various movements that centre on women}

The Women's Liberation movement was initiated in America in the 1960s. The aim of the feminist movement was to place women on an equal footing with men. The original contribution of feminism was to combat the 'patriarchal' conceptions of male and female roles in society. The movement also draws a distinction between sex and gender to redefine male and female roles, and confronts sexual oppression in domains such as reproduction, production, sexuality and socialization.

One central criticism levelled by Africans, is that feminism does not see beyond Western societies, and this perspective ignores or marginalizes the specific problems of African women. Feminism often goes to the opposite extreme by presuming to be able to speak in the name of all women without, however, having really informed itself about the situation and the problems of women in other parts of the world. As a consequence, non-African feminists tend to base their assessment of the situation and the emancipatory ideas of African women and women's movements on their personal views and experiences. It is for this reason that African women resorted to various terms that have been coined specifically to cater for their needs.

The question whether or not to impose a foreign theory on African women is a debatable one. In order to bypass these concerns, Africans have deemed fit to devise a theory that caters for the needs of women in Africa. As a result, some African scholars such as Ongunyemi (1985:72), prefer the term womanism.

According to Arndt (2000:711), Ongunyemi arrived at the term womanism independently from and at about the same time as Alice Walker. While she used the term womanism without a modifier previously, today she speaks specifically of African womanism. Although her conceptions have important parallels with Walker's versions of womanism, there are decisive differences too. Ongunyemi's African womanism is widely known, although it is not as famous as Walker's womanism. In fact, she is one of the most important scholars of African women's literature, and her work has had a great influence on the mainstream discourse in the field.

The most substantial difference is that Ongunyemi (1985:12) wishes to conceptualize an ideology that clearly demarcates and emancipates African women from both white feminism and African-American womanism/ feminism (my emphasis). She justifies this as follows:

Since feminism and African-American womanism overlook African peculiarities, there is a need to define African womanism. It is necessary to reiterate that the womanist praxis in Africa has never totally identified with all the original Walkerian precepts. An important point of departure is the African obsession to have children. 
Only African women may be African womanists in Ongunyemi's sense. Besides this general demarcation from African-American womanism/feminism, Ongunyemi also explicitly dissociates herself from Walker. Another difference in content manifests itself in their incompatible attitudes toward lesbianism. While Walker emphasizes that womanists love other women, 'sexually and/or non sexually', Ongunyemi argues that her African womanism rejects lesbian love because of the African silence on, or intolerance of lesbianism. The core of Ongunyemi's definition of African womanism is that:

An African womanist will recognize that, along with consciousness of sexual issues, she must incorporate racial, cultural, national, economic and political considerations to her philosophy. Moreover, an African womanist must deal with, among other things, interethnic skirmishes and cleansing, religious fundamentalism, the language issue, gerontocracy and in-lawism (Arndt, 2000:712).

According to Arndt, Ongunyemi criticizes white Western feminism for being gender centred. Moreover, she argues that white feminists either ignore African women's problems completely or speak in the name of all women without being sufficiently informed about the situations and problems of women from other cultures. According to Ongunyemi, African-American womanism overlooks African peculiarities, too. The fundamental argument of African scholars such as Kolawole (1997) and Molara Ogundipe-Leslie (1994), is that they all agree that a foreign theory is inapplicable to an African woman.

For the purpose of this article, the views of both African and Western scholars will be debated. It should be borne in mind that Africa does not exist in isolation; it needs to coexist with the international world. Ongunyemi (Arndt, 2000:713) also suggests that there should be cooperation between Western feminism and African womanism but that Western feminists should take cognizance of the reality that Africa is still experiencing, and that there are problems that have to be solved.

This is summed up by Mariama Ba, as quoted by Arndt (2002:67), when she states that:

There is everywhere ... in the world a woman's cry being uttered. The cry may be different, but there is still a certain unity ... The cry that they utter, the women from these other countries, their cry will not exactly be the same as ours - we have not all got the same problems - but there is a fundamental unity in all our sufferings and in our desire for liberation and in our desire to cut off the chains which date from antiquity.

Before embarking on the depiction of Mkabayi, her brief history will be presented.

\section{Brief historical background of Mkabayi kaJama}

Princess Mkabayi of the Zulus is acknowledged to have been a callous woman. Being one of twins, she was destined to be killed in infancy according to tradition. Her compassionate father, King Jama, could not bring himself to kill his own offspring, so Mkabayi and her twin sister, Mmama, both survived, much to the displeasure and disapproval of the Zulu people. They feared the wrath of the ancestors should both the twins be allowed to live. This fear became a reality when the queen died before bearing the dynasty an heir. Because Mkabayi had a stronger character than her twin sister, she bore the brunt of the Zulu people's disapproval and hate. She was held responsible for all the misfortunes of the royal family and the populace at large.

When Mkabayi realized that the Zulu people were still yearning for an heir, she wooed Mthaniya for her rather indifferent father. The king consequently married Mthaniya and this union produced the long-awaited heir, who was named Senzangakhona (Well-doer). This name reflected King Jama's acknowledgement that Mkabayi had done well to court Mthaniya for him. This swayed the hearts of the nation towards her, especially since the erratic Jama had offended his subjects once again by marrying a pregnant Thonga woman who had given birth to Sojiyisa. The nation feared that this illegitimate boy would inherit the Zulu throne. 
Mkabayi soon lost the love she had gained from the Zulu people when, on the death of Jama, she imposed herself on the nation as regent for her brother Senzangakhona. This was unheard of in Zulu history, but men succumbed to her guile and domineering character.

Her unscrupulousness shocked the nation once again when she instructed her army to destroy the powerful Sojiyisa, who posed a threat to Senzangakhona's reign. She was dubbed a blood-thirsty despot and one of the evil women of antiquity, a woman whose primary aim was the continuance of the Zulu dynasty and its traditions.

When Senzangakhona came of age, Mkabayi stepped down in his favour, but unfortunately, Senzangakhona was not destined to live long. After a short reign, he was succeeded by his son, Shaka, one of the most able emperors the world has ever known. Shaka, on ascending the throne, ruled his people without recourse to anyone for advice.

Yet, despite Shaka's success, when he was accused of abusing his power, Mkabayi did not hesitate to plot the assassination of a man who was to become the first and most powerful of the Zulu kings. She, together with her nephews, Dingane and Mhlangana, planned the murder of Shaka. Desirous of putting Dingane on the throne, she later murdered Mhlangana.

Mkabayi remained unmarried, preferring to retain her independence, political influence and position as head of the Qulusi military kraal. She played a major role in Zulu history, deposing various kings and helping them ascend to the throne; her power and influence were felt during this time which was of great historical importance to the Zulu nation. Many years later, when Captain Gardiner went to Dingane on missionary work, he found her old, but still very powerful (Fynn, 1950:12). She died a lonely woman during the reign of Mpande. For her part in the killing of Shaka, Mkabayi stands condemned to the present day.

\section{Praise poem of Mkabayi}

USoqili!

Iqili lakwaHoshoza

Elidl'umuntu limyenga ngendaba;

Lidl'uBhedu ngasezinyangeni,

Ladl'uMkhongoyiyana ngasemaNgadini,

Ladl' uBheje ngasezanuseni.

UBhuku lukaMenzi,

Olubamb'abantu lwabenela;

Ngibone ngoNohela kaMlilo, umlil'ovuth'intaba zonke,

Ngoba lumbambe wanyamalala.

Inkom'ekhal' eSangoyana,

Yakhal' umlomo wayo wabhoboz'izulu,

Iye yezwiwa nguGwabalanda

Ezalwa nguNdaba wakwaKhumalo.

Intomb' ethombe yom'umlomo.

Zaze zayihlab'imithanti zawonina.

UMthobela-bantu izinyoni,

Bayazibamba usezibuka ngamehlo.

UVula-bangene-ngawo-onk'amasango,

Abanikazimuzi bangene ngezintuba.

UMcindela kaNobiya,

UMhlathuz' uzawugcwal' emini.

Imbibakazan' eyaqamb imigqa kwaMalandela,

Yathi ngabakwaMalandela,

Ithi yikhona bezoqananaza ngazo zonk'izindlela .

(Cope, 1968:173) 
'Father of guile!

Cunning one of the Hoshoza people,

Who devours a person tempting him with a story;

She killed Bhedu amongst the medicine men,

And destroyed Mkhongoyiyana amongst the Ngadini,

And killed Bheje amongst the diviners.

Morass of Menzi,

That caught people and finished them off;

I saw by Nohela son of Mlilo, the fire-that-burns-on-every-hill,

For it caught him and he disappeared.

Beast that lows at Sangoyana,

It lowed and its voice pierced the sky,

It went and it was heard by Gwabalanda

Son of Ndaba of Khumalo clan.

Maid that matured and her mouth dried up,

And then they criticized her amongst old women.

Who shoots down birds for her people,

As they catch them she is simply watching on.

The opener of all main gates so that all people may enter,

The owners of the home enter by the narrow side-gates.

Sipper of others of the venom of the cobra,

The Mhlathuze river will flood at midday.

Little mouse that started the runs at Malandela's,

And thought it was the people of Malandela

Who would thereby walk along all the paths.'

\title{
Analysis
}

In the first stanza we have these lines:

\author{
USoqili! \\ Iqili lakwaHoshoza \\ Elidl'umuntu limyenga ngendaba \\ Lidl' uBhedu ngasezinyangeni, \\ Ladl'uBbheje ngasezanuseni \\ Ubhuku lukaMenzi \\ 'Father of Guile! \\ Cunning one from Hoshoza \\ She killed Bhedu amongst the medicine men, \\ And killed Bheje amongst the diviners. \\ Morass of Menzi'
}

In the opening line, Mkabayi is addressed as Soqili, 'Father of Guile'. This is a male salutation. She was commonly referred to as Baba, which is indicative of her importance and standing among the Zulus. This name transported her from the subservient and insignificant status of a woman, to one of a prince and later, a father figure, commanding the utmost respect and obedience.

Turner (1990:6) states that Koopman (1988), in his study of Zulu names, notes the fact that the morpheme -sodoes not necessarily mean 'father' or 'owner of' as claimed by Doke (1958), who records it as a contraction of the old Bantu form of uyihlo, but can be used purely as a male marker. However, Koopman's interpretation seems fitting here.

The powerful metaphor used here deserves a mention. Msimang (1991:66) explains that the idea of Mkabayi being likened to a morass has significance in that she was a dangerous and powerful woman who was responsible 
for the deaths of kings (Shaka) and commoners alike, but her appearance was deceptive. She was ostensibly a shy person, who remained unobtrusive. Like marsh, her presence was inviting, but her victims soon got themselves bogged down and died (like Mbopha and Mhlangana, who were enticed by Mkabayi to take part in her plot to kill Shaka, but who were eventually murdered in turn without any of the promises made to them having been fulfilled). Another facet of this vivid metaphor which illuminates Mkabayi's character, is the fact that she never actually wrestled with her victims, but instead connived and plotted behind the scenes. Like the marsh, she too was passive, and the more the victims resisted the inevitable, the more they submerged themselves, leaving no tell-tale evidence behind.

In most cases, women are depicted as docile and helpless. However, Mkabayi assumed powerful attributes that are normally associated with men, thereby contradicting the stereotype that women are always docile and submissive. She was a brave, quick thinking woman who was prepared to take risks. It should be borne in mind that Mkabayi lived in a male-dominated and cut-throat environment where her decisions were questioned with cynicism because of her gender. She lived in an environment where the men were supposed to rule the country and the women to obey the rules. Hence, as a survival skill, she resorted to shrewdness, plotting and conniving tactics to secure her position as the ruler of an empire as big as the Zulu nation. A man might naturally also have resorted to these tactics for the sake of survival.

In the following lines, Mkabayi (like Shaka) is associated with a beast, another very rich metaphor.

Inkom' ekhal' eSangoyana,
Yakhal' umlomo wayo wabhoboz' izulu,

'Beast that lows on Sangoyana,

It lowed and its voice pierced the sky,'

This emphasizes the fact that when Mkabayi spoke, kings and commoners alike listened in silence. This is due to her undeniable influence as a power behind the throne of the descendants of Malandela, her dangerous and ruthless side, as evidenced by the dead already named.

Mkabayi's association with a beast is a great honour because owning livestock is a male preserve and only men can make decisions as far as cattle are concerned. In terms of Zulu customs, the cow has connotations of wealth, ritual and legal value. In terms of ilobolo 'dowry', they are regarded as being a life-giver on account of the meat and milk they provide, apart from several other valuable properties they possess, such as the hide and horns used for clothing by the inyangas 'traditional doctors'. This implies that Mkabayi was awarded the status of a man - a powerful and quick thinking one at that.

Eisenstein (1988:39) comments by saying:

The moment of truth, in consciousness-raising, came at the point where the 'exceptional woman' understood that to be told 'You think like a man' was to be told, 'You are not a "real woman" and (simultaneously), "Real women are inferior to men".'

It would have been an insult to Mkabayi to be told that she thought like a man because she was indeed equal to a man in deeds and thoughts.

In the following lines:

Intomb' ethombe yom'umlomo

Zaze zayihlab' imithanti ezawonina. 
'Maid who grew to maturity and her mouth dried up

And then they criticized her amongst the old women.'

Zibani (1997:28) is of the opinion that these verses are open to many possible interpretations, but two possibilities will be considered. They could refer to:

- her rejection of men who wanted her in marriage. The elderly people may have scolded her, showing their disapproval of her behaviour

- Mkabayi's venture and determination to be her brother's regent, while he was still young. The elderly people disapproved of a woman's taking up kingship, which was regarded as a male prerogative.

In IsiZulu we say, Umuntu ukhuluma kome umlomo, meaning: 'she or he speaks clearly, leaving no room for misunderstanding and misinterpretations'. Possibly, this is what Mkabayi did when she announced her intention to become a regent for Senzangakhona, her younger brother, and vowed to denounce marriage and devote her entire life to building the nation.

In African society, an old lady mostly symbolizes female integrity. She is regarded as the custodian of social values. The old women in Mkabayi's praise are appalled by Mkabayi's 'deviant' behaviour. In a society where women are expected to toe the line, Mkabayi seemed to have 'freed' herself from social expectations. Little (1980:134) describes a free woman as follows:

By 'free woman' is meant one who flouts or disregards conventional beliefs concerning the proper role and position of the female sex. One of the common of these beliefs is that it is wrong for a woman on her own to take a major decision. This is a male prerogative. It is also wrong to undertake roles, including occupational ones, traditionally ascribed to the male sex. Perhaps the most common belief of all is that a woman's place is in the home and her duty is to marry and have children.

Society, particularly African, predetermines the role girls must play. Every girl learns these gender-linked roles from infancy and they are reinforced as she goes through the various stages of her life. This leaves those affected with no choice in the end. This convention did not apply to Mkabayi, as she stood her ground.

The following lines commend Mkabayi for her diplomatic skills as she was able to settle the people's problems and she was easily approachable. She was an avenue of advancement for people, regardless of status, and they used her position as a go-between, providing commoners with access to the throne.

Bayazibamba usezibuka ngamehlo

UVula-bangene-ngawo-onk-amasango,

Abanikazimuzi bangene ngezintuba.

'They catch them and she looks at them with her eyes.

The opener of all gates so that people may enter,

The owners of the home enter by the narrow side-gates.'

Mkabayi is depicted as a woman who had a good side to her. She was approachable as a ruler and her subjects felt comfortable enough to air their grievances. She ruled by the precept: Inkosi inkosi ngabantu 'a king is a king by its people'. A clever ruler prioritized and made time for his/her subjects. Winning the hearts of the nation through diplomatic skill has always been an indispensable attribute in a ruler.

Subjects like to be in the company of their king, and Mkabayi and King Shaka were always accessible during their reign. King Dingane, unlike his predecessors, recoiled from the public eye and kept to himself in order to brood on his evil plots without any disturbances. Obviously this conduct did not meet with the approval of his subjects. They started comparing him to Shaka who was always in the company of his people, especially the council. This is why 
the bard indicated that the people would like to have an audience with their king; they would like to communicate with them. These lines suggest Dingane's recoil from the public (Msimang, 1991:57).

\author{
USingqungqu kakhulumi, \\ Kanamlomo, \\ AkanjengaShaka \\ Akanjengo Dlondlwane lwakithi lwakwaBulawayo \\ Lona olwaqed' umuzi ngokunkenkeza
}

UMshingili ongazindlovu ...

'Quiet one, he speaks not,

He is mouthless;

He is unlike Shaka,

He is not like our Dlodlwane from Bulawayo

Who finished off the household by chattering

Turner away like elephants ...'

The above stanza shows a difference of character between Mkabayi and Dingane.

The following line:

UMcindela kaNobiya,

'Mcindela, descendant of Nobiya',

depicts Mkabayi as a person who protected others from the displeasure of the king, thereby dealing with very tricky and dangerous situations, as reinforced by the image of the cobra. She opposed the abuse of power, especially when it came to protecting the subjects from the wrath of the king. She knew how to handle most of the kings who ascended the throne because she had made most of them. In fact, Mkabayi's word was law.

Mkabayi ruled in accordance with womanist ideas.

Womanists are concerned about the entire community and are holistic in approach, which means that both men and women can come together in a dialogue to define and address the needs of the entire community (Nkumane, 1999:28).

This holistic approach means that womanism is a non-elitist movement. It does not prioritize people's needs according to the particular social class to which they belong. Hence, it is virtually classless. It considers all people in the community, male and female. The recurrent humanist vision is central to black feminism. It is more closely associated with human solidarity than anything else.

The following line sketches another image of Mkabayi, which affirms her greatness:

UMhlathuz' uzawugcwal'emini.

'The Mhlathuze river will flood at midday.'

The Mhlathuze river is used as a metaphor to indicate the qualities of size and importance, as well as unpredictability (in terms of unexpected flooding). This can be compared with Mkabayi's moodiness and occasional erratic behaviour.

Reber (2005, as quoted by Nkumane, 1999:130), has this to say about hysteria: 
Hysteria is kind of emotional outburst and was viewed as a psychiatric female disorder. Hysteria, was, until recently, assumed to be solely a dysfunctional disease of women caused by a wandering uterus. He continues to explain that the link in psychoanalytic theory has helped in providing a more reasonable etiology but the link between gender and the disorder has not been completely severed, males were rarely diagnosed.

The above quotation confirms one of the many stereotypes that are attached to women. The stereotype that women think with their ovaries is one stereotype that is intended to dishearten a woman or to demoralize her when she is faced with a difficult decision. Since it cannot be proved that hysteria is a female attribute, it would be unfair to conclude that Mkabayi's temperamental behaviour was a result of her wandering uterus. Any person in any leadership position, male or female, could be prone to temperamental behaviour since ruling a country as huge as the territory of the Zulu nation was a mammoth task.

These concluding lines contain an interesting metaphor used by the imbongi 'bard'. Mkabayi is likened to a little mouse, elusive and secretive in its movements, an image which depicts her as someone who concealed her true self and preferred to work in secrecy. We are reminded of her status as a mere woman, who was to be the guiding light and power behind the throne of the descendants of Malandela.

Imbibakazan'eyaqamb'imigqa kwaMalandela,

Yathi ngabakwaMalandela,

Ithi yikhona bezoqananaza ngazo zonk' izindlela

'Little mouse that started the paths at Malandela

And thought it was the people of Malandela

Who would thereby command all the routes.'

An interesting point to note here, is the complete lack of any physical references in Mkabayi's praise poem. This may be due to the fact that Mkabayi did not have any exceptional physical oddities, and therefore the bard did not touch on physical attributes. Although Mkabayi's praise poem does not mention any physical attributes such as bodily beauty and other qualities expected from a Zulu woman, this may be ascribed to the fact that Mkabayi was never really considered as being a woman in the usual sense, in Zulu society at the time.

The fact is that she shunned marriage and played an active role in the nurturing of the Zulu nation as such. She was regarded as being a prince, not a princess, and was accordingly addressed as Baba by all her subjects and her nephews, who became the powerful rulers of the Zulu nation. As a result, we find Mkabayi's praises being very similar in content to the large body of praises that were composed in honour of men, and she displays the qualities that are highly regarded among them.

Mkabayi defied all odds and placed herself on a par with men, the elite group that governed before her. It takes a radical and strong personality to venture into such a patriarchal territory. Moore (1992:30) has this to say about the radical ideology:

The radical feminists argue that the most fundamental of oppression is patriarchy. In order for women to be free from oppression, the patriarchal structures of society must change. They argue further that women's oppression is biologically based since women are tied to childbirth and childbearing processes, which continually place them in [a] position of dependence on men to survive. They call for the women's movement to participate in a 'biological revolution', freeing women from their biological oppression.

In any given cultural context, male and female behavioural patterns are fixed by norms. Mkabayi is depicted as a hardcore feminist, a radical one. She flaunts the conventions of her society, such as marriage and childbearing, obedience and submissiveness. It could be argued that it was possible for her to flaunt some of the norms because of the powerful person she was and the position that she occupied. 


\section{Conclusion}

Mkabayi's praises have attested that, given the opportunity, women are capable of achieving any goals they set their sights on. In days gone by, it was unusual in African societies for a woman to command men as to how, when and how to behave.

Mkabayi's strong character and willpower proved her critics wrong. Growing up, she and her twin sister were taunted and stigmatized, twins being seen as the ultimate mishap. Mkabayi made and destroyed kings. It is no wonder that she is addressed as -Soqili- in line 1 of her praise poem. She has been depicted as a woman who possesses the same cardinal virtues as men. She evinced the qualities of a strong and brave leader, a strategic thinker and a queen who listened to the pleas of her nation. Her praises bring home the point that even under difficult circumstances, women can achieve equal opportunities and equal rewards for their efforts. Running through this praise poem is the theme of the Renaissance woman whose courage, assertiveness and stubborn fairness gave her the will to survive against all odds.

\section{References}

Arndt, S. 2000. African gender trouble and African womanism: An interview with Chikwenye Ongunyemi and Wajira Muthoni. Signs: Journal of Women in Culture and Society 25(31):709-726.

Arndt, S. 2002. The dynamics of African feminism: Defining and classifying African feminist literatures. Trenton: Africa World Press.

Cope, A.T. 1968. Izibongo: Zulu praise poems. Oxford: Clarendon Press.

Doke, C.M. 1958. English and Zulu dictionary. Johannesburg: Wits.

Eisenstein, H. 1988. Contemporary feminist thought. London: UnWin.

Fynn, H.F. 1950. The diary of Henry Francis Fynn. Pietermaritzburg: Shuter \& Shooter.

Gunner, E. 1991. Musho! Zulu popular praises. Cape Town: Creda Press.

Kolawole, M.E.M. 1997. Womanism and African consciousness. Trenton: Africa World Press.

Koopman, A. 1988. The social and literary aspects of Zulu personal names. Pietermaritzburg: University of Natal.

Little,K. 1980. African women in towns: An aspect of Africa's social revolution. Cambridge: Cambridge University Press.

Moore, H.A. 1992. Sociology of women: The intersection of patriarchy, capitalism and colonization. New Jersey: Prentice Hall.

Msimang, C.T. 1991. A review of the praises of Dingane. South African Journal for Folklore Studies 2:51-60.

Nkumane, K.G. 1999. Themes of forced and forbidden love: Cross-cultural trends in language literatures with special reference to Zulu novels. Unpublished DLitt et Phil thesis. Johannesburg: Vista University.

Ogundipe-Leslie, M. 1994. Recreating ourselves. African women and critical transformations. New Jersey: Africa World Press.

Ongunyemi, C.O. 1985. Womanism: The dynamics of the contemporary black female novel in English. Signs: Journal of Women in Culture and Society 2(1):63-80.

Reber, J.S. 2005. Critical thinking about psychology: Hidden assumptions and plausible alternatives. Washington DC: American Psychology Association.

Turner, N. 1988. Comparison of the izibongo of the Zulu royal women, Mkabayi and Nandi. South African Journal of African Languages 8(1):28-33.

Turner, N. 1990. Elements of satire in Zulu oral traditions. Unpublished M.A. dissertation. Durban: University of Natal.

Zibani, N. 1997. Some features of Zulu praise poetry for women. Unpublished Honours article. Durban: University of Zululand. 